\title{
Nuclear Markers (AFLPs) and Chloroplast Microsatellites Differ Between Fagus sylvatica and F. orientalis
}

\author{
By O. GAILING ${ }^{1}$ and G. von Wuehlisch ${ }^{2}$ \\ Institute of Forest Genetics and Forest Tree Breeding, \\ Georg-August-University Göttingen, Büsgenweg 2, D-37077 Göttingen, Germany \\ ogailin@gwdg.de; Tel.: 049-551-3914281
}

(Received $1^{\text {st }}$ March 2004)

\begin{abstract}
Former studies based on chloroplast markers and allozymes suggested that postglacial recolonization of central Europe by Fagus sylvatica L. occurred from one or a few undifferentiated refuges. Here, we examine $F$. sylvatica from Germany and Greece and different provenances of $F$. sylvatica ssp. orientalis (Lipsky) Greut \& Burd. (F. orientalis Lipsky) with chloroplast microsatellites and AFLP markers. Only such AFLP markers were selected that had shown a differential amplification in $F$. sylvatica and $F$. orientalis in a preliminary analysis. UPGMA cluster analysis of AFLP data distinguished one $F$. sylvatica group and one $F$. orientalis group from northern Turkey. Low structuring in the neighborjoining analysis and the lack of diagnostic bands for either taxon suggests a relatively recent differentiation in Fagus orientalis and F. sylvatica. High bootstrap values were only found for a separate cluster that comprises $F$. orientalis from two different forest botanical gardens. Four of these samples have a unique chloroplast type and are genetically very similar (bootstrap value 96) mostly likely due to clonal replication. Only two different chloroplast types (type 1 in Germany, type 1 and type 2 in Greece) could be detected for $F$. sylvatica. In contrast, $F$. orientalis from northern Turkey showed different chloroplast types even within one provenance pointing to a glacial refuge in northern Turkey and a bottleneck at the time of postglacial recolonization of central Europe. The classification of ten samples from northern Turkey as $F$. sylvatica by AFLP data, chloroplast markers and morphology questions the interpretation of $F$. orientalis and $F$. sylvatica as two geographically separated (allopatric) taxa.
\end{abstract}

Key words: Fagus sylvatica, Fagus orientalis, AFLP, cpDNA.

\section{Introduction}

Fagus sylvatica L. is the most important broad-leaved tree species in Germany and is dominant in many parts of Europe. Most populations in central Europe are genetically uniform in maternally inherited chloroplast markers suggesting a bottleneck at the time of postglacial recolonization (DEMESURE et al., 1996). Studies with cpDNA, allozymes and fossil pollen data are in accordance with the recolonization of Europe from one refuge or from several undifferentiated refuges in southeastern Europe (DEMESURE et al., 1996, GÖMÖRY et al., 1999, HuNTLEY and BIRKS, 1983). Isolation of populations during cold phases of the Pleistocene resulted in the formation of different geographical races in refugial areas (DENK et al., 2002). Cluster analysis of morphological characters (leaf and fruit characters) distinguished two morphotypes corresponding to European Fagus ( $F$. sylvatica L. and $F$. sylvatica var. moesiaca Maly (synonymous to F. moesiaca (Maly) Czeczott)) and western Asian beech ( $F$.

1) Institute of Forest Genetics and Forest Tree Breeding, Georg-AugustUniversity Göttingen, Büsgenweg 2, 37077 Göttingen, Germany. ogailin@gwdg.de; Tel.: 049-551-3914281

2) Federal Research Centre for Forestry and Forest Products, Institute for Forest Genetics and Forest Tree Breeding, Sieker Landstrasse 2, 22927 Grosshansdorf, Germany. orientalis Lipsky $=F$. sylvatica ssp. orientalis (Lipsky) Greuter $\&$ Burdet) (DENK et al., 2002). Clinal variation of morphological characters and low resolution of ITS (Internal Transcribed Spacer) cladograms suggested that $F$. sylvatica, $F$. orientalis and morphologically intermediate $F$. moesiaca can be regarded as a single species (DENK et al., 2002). However, distribution ranges of eastern beech and European beech are supposed to be quite distinct with only a small contact zone in south eastern Europe indicating a limited gene flow between taxa (GöMÖRY et al., 1999). In the present study, AFLPs (Vos et al., 1995) and chloroplast microsatellites (WEISING and GARDNER, 1999) are used to reveal the (intraspecific) relationship between $F$. sylvat$i c a$ from Greece and Germany and $F$. orientalis from northern Turkey. The marker system is also applied in F. orientalis samples from two forest botanical gardens. The following questions are addressed: (1) Are $F$. sylvatica and $F$. orientalis two distinct (allopatric) species or is there evidence for gene exchange suggested by the clinal variation of morphological characters (DENK et al., 2002)? (2) Is the marker system applicable for the identification of plant material from unknown origin (for example, from botanical gardens)?

\section{Materials and Methods}

\section{Plant material}

The seed samples for the International Beech Provenance Trial were collected in Turkey during October 1983 and sent to the Institute at Großhansdorf for rearing of plants. In the winter 1986/87 the trials were established with three-year old seedlings. Details on the trial lay-out are given elsewhere (WueHLISCH et al., 1998). During an inspection of the field trial by Prof. L. Paule, morphological characters of most of the trees of provenance Devrek originating from Tefen-Kirkdere, forest district Devrek, Turkey, were found to resemble $F$. sylvatica
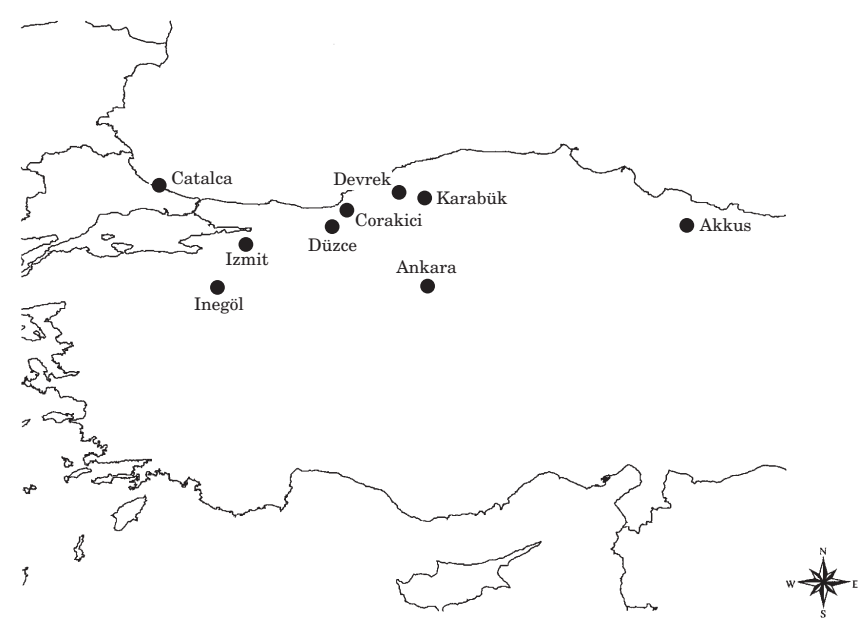

Figure 1. - Location of origin in North-West Turkey of the eight provenances analysed. 


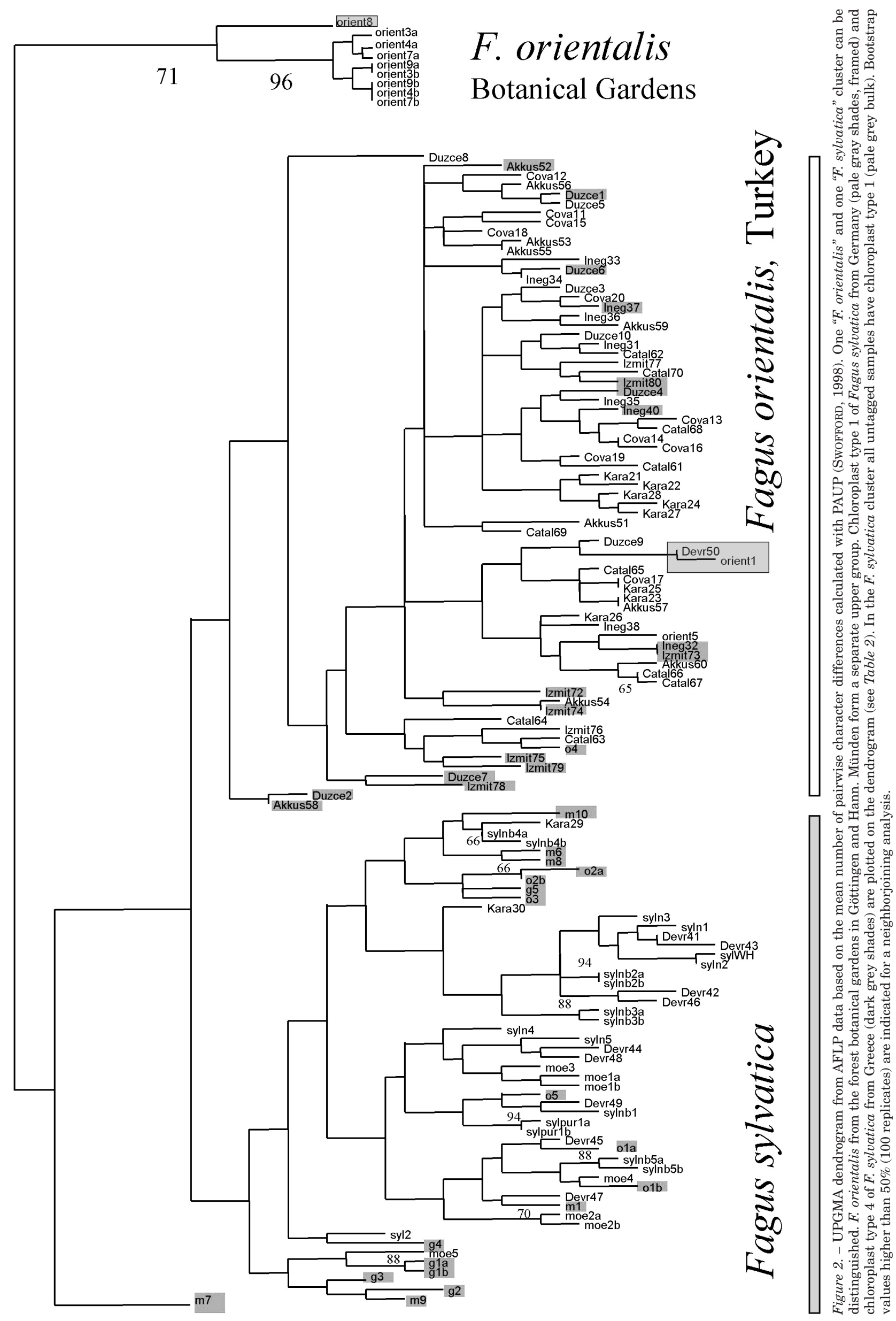


rather than $F$. orientalis. Also, the analysis of isozyme gene loci of this provenance showed allele frequencies to resemble those of $F$. sylvatica rather than those of $F$. orientalis (GöMÖRY, pers. communication). However, the morphology of the other seven provenances originating from Turkey appeared to be typical for $F$. orientalis. The geographic origin of $F$. orientalis populations is shown in Figure 1. Plant material that has been collected from $F$. orientalis trees from botanical gardens was verified as $F$. orientalis by leaf morphology and by characteristics of the cupulae. F. orientalis trees from the forest botanical garden in Göttingen are about 35 years (orient 3), 20 years (orient 1) and about 10 years old (orient 4,5 ). The three $F$. orientalis trees from the forest botanical garden in Hann. Münden have an estimated age of about 80 years (orient $7,8,9$ ).

\section{DNA isolation}

DNA was extracted from buds using the Dneasy ${ }^{\mathrm{TM}}$ Plant Minikit (Qiagen, Hilden, Germany). DNA amount was tested on a $0.8 \%$ agarose gel after staining with ethidium bromide.

\section{Molecular markers}

AFLP reactions were carried out according to the protocol of Vos et al. (1995) with slight modifications. Genomic DNA was restricted with $E c o$ RI and $M s e I$. A preselective amplification was performed with the primer combination E01/M03 (nomenclature according to Keygene, http://wheat.pw.usda.gov/ ggpages/keygeneAFLPs.html) with the following PCR profile: a first step of $2 \mathrm{~min}$ at $72^{\circ} \mathrm{C}$ followed by 20 cycles of $10 \mathrm{~s}$ at $94^{\circ} \mathrm{C}$, $30 \mathrm{~s}$ at $56^{\circ} \mathrm{C}, 2 \mathrm{~min}$ at $72^{\circ} \mathrm{C}$ and an extension step for $30 \mathrm{~min}$ at $60^{\circ} \mathrm{C}$. Four microliters of the preselective amplification product were used in the selective reaction with the primer combinations E38/M64 and E37/M68. The PCR profile was a denaturation at $94{ }^{\circ} \mathrm{C}$ for 2 min followed by nine cycles with 10 s at $94^{\circ} \mathrm{C}$, a $30 \mathrm{~s}$ annealing step at $65^{\circ} \mathrm{C}$ and 2 min at $72^{\circ} \mathrm{C}$. The initial annealing temperature of $65^{\circ} \mathrm{C}$ was reduced in each cycle by $1^{\circ} \mathrm{C}$. The last 24 cycles were performed with an annealing temperature of $56^{\circ} \mathrm{C}$ ending with $30 \mathrm{~min}$ at $60^{\circ} \mathrm{C}$. The selective PCR reactions were carried out with EcoRI primers that were labelled with the fluorescent dyes 6-FAM and HEX. All PCR reactions were performed in the Peltier Thermal Cycler (PTC-0200 version 4.0, MJ Research). Fragments were separated on the ABI Genetic Analyser 3100 together with the internal size standard GS 500 ROX (fluorescent dye ROX) from Applied Biosystems. The size of the AFLP fragments was determined with the software packages Genescan 3.7 and Genotyper 3.7 (Applied Biosystems). Absence and presence of fragments of specific sizes were recognized and transformed into a 0/1 matrix (script for Genotyper 3.7 was kindly provided by Applied Biosystems). For 14 samples (designated with a resp. b in Figure 2) the AFLP procedure was repeated beginning with the restriction ligation reaction.

Chloroplast microsatellite markers were amplified according to WEISING and GARDNER (1999) and tested for polymorphisms in $F$. sylvatica and F. orientalis. Primer pairs ccmp4, ccmp 7 and ccmp10 were amplified in the total sample, since they show variation in F. sylvatica (VENDRAMIN, personal communication). Only ccmp 7 showed polymorphisms in our samples. Amplification products of ccmp4, ccmp 7 and ccmp 10 were separated on a $2 \%$ agarose gel and excised from the gel. Gel extraction was performed with QIAEX II (Qiagen). The sequencing reactions were carried out with the Big Dye Terminator v.3.1 Cycle Sequencing Kit (Applied Biosystems) and run on the ABI 3100 Genetic Analyser. The chloroplast microsatellites were amplified in all 133 samples with one primer (the forward primer) labelled with the fluorecent dyes 6-FAM or HEX. In addition, reproducibility of the method was tested by the application of a temperature gradient from 40 to $52{ }^{\circ} \mathrm{C}$ annealing temperature $\left(\mathrm{T}_{\mathrm{a}}\right.$ ) for $c c m p 7$ in samples that represented all detected alleles (fragment sizes). Fragments were separated on the ABI 3100 sequencer and analysed as described above.

\section{Data analysis}

AFLP data were used to calculate an UPGMA (Unweighted Pair-Group Method Analysis) dendrogram from the mean number of pairwise character differences with the software package PAUP 4.0b10 (SWOFForD, 1998). Clusters were used to search for markers that are preferentially amplified in the one or in the other cluster. A neighborjoining tree with 100 bootstrap replicates was calculated.

\section{Results}

\section{cpDNA variation}

For chloroplast microsatellite $c \mathrm{cmp} 7$, one single allele (145 $\mathrm{bp}$, type 1) was found in $F$. sylvatica from different locations in Germany (Table 1, 2). Five other F. sylvatica samples from Mt. Olymp (Greece) classified as intermediate between $F$. orientalis and $F$. sylvatica ( $F$. sylvatica var. moesiaca) by leaf morphology showed chloroplast type 1 as well. Three $F$. sylvatica populations from Greece (from Mt. Olymp, Piera Mountains, Gardiki) revealed a different chloroplast type $(148 \mathrm{bp}=$ type 4$)$.

ccmp 7 was highly variable even within populations of $F$. orientalis from northern Turkey displaying seven different alleles represented by fragment sizes from $145 \mathrm{bp}$ to $151 \mathrm{bp}$ (Table 2). In $F$. orientalis samples from forest botanical gardens three alleles could be observed, the most frequent one (152 bp) is absent in the material from northern Turkey. Chloroplast type1 (common in Germany) was observed in one sample of $F$. orientalis from the forest botanical Garden in Göttingen (orient 1), in all 10 samples of population Devrek and in 2 out of 8 samples from population Karabük from northern Turkey. Chloroplast type $4(148 \mathrm{bp})$ that is characteristic for the investigated

Table 1. - Provenances of Fagus sylvatica and F. orientalis.

\begin{tabular}{|c|c|c|c|c|c|c|c|c|}
\hline $\begin{array}{l}\text { taxon } \\
\text { description }\end{array}$ & country & region & name & $\begin{array}{l}\text { number } \\
\text { of trees }\end{array}$ & location & latitude & longitude & $\begin{array}{l}\text { altitude } \\
\text { (m) }\end{array}$ \\
\hline orientalis & Turkey & Corakici & Cora & 10 & $\begin{array}{l}\text { provenance } \\
\text { test }\end{array}$ & $41^{\circ} 03^{\prime}$ & $31^{\circ} 17^{\prime}$ & 900 \\
\hline orientalis & Turkey & Düzce & Duzce & 10 & $\begin{array}{l}\text { provenance } \\
\text { test }\end{array}$ & $40^{\circ} 51^{\prime}$ & $31^{\circ} 09^{\prime}$ & 1050 \\
\hline orientalis & Turkey & Akkus & Akkus & 10 & $\begin{array}{l}\text { provenance } \\
\text { test }\end{array}$ & $40^{\circ} 50^{\prime}$ & $37^{\circ} 05^{\prime}$ & 1250 \\
\hline orientalis & Turkey & Catalca & Catal & 10 & $\begin{array}{l}\text { provenance } \\
\text { test }\end{array}$ & $41^{\circ} 28^{\prime}$ & $28^{\circ} 21^{\prime}$ & 350 \\
\hline orientalis & Turkey & Inegöl & Ineg & 10 & $\begin{array}{l}\text { provenance } \\
\text { test }\end{array}$ & $39^{\circ} 53^{\prime}$ & $29^{\circ} 36^{\prime}$ & 1300 \\
\hline orientalis & Turkey & Izmit & Izmit & 10 & $\begin{array}{l}\text { provenance } \\
\text { test }\end{array}$ & $40^{\circ} 34^{\prime}$ & $29^{\circ} 57^{\prime}$ & 1250 \\
\hline orientalis & Turkey & Karabük & Kara & 10 & $\begin{array}{l}\text { provenance } \\
\text { test }\end{array}$ & $41^{\circ} 17^{\prime}$ & $32^{\circ} 32^{\prime}$ & 900 \\
\hline orientalis & Turkey & Devrek & Devre & 10 & $\begin{array}{l}\text { provenance } \\
\text { test }\end{array}$ & $41^{\circ} 16^{\prime}$ & $32^{\circ} 17^{\prime}$ & 950 \\
\hline orientalis & unknown & $\begin{array}{l}\text { bot. } \\
\text { garden }\end{array}$ & orient & 7 & $\begin{array}{l}\text { forest bot. } \\
\text { garden }\end{array}$ & & & \\
\hline sylvatica & Germany & & $\begin{array}{l}\text { sylnb } \\
\text { syln } \\
\text { syl }\end{array}$ & 13 & $\begin{array}{l}\text { Göttingen, } \\
\text { Solling, } \\
\text { forest bot. } \\
\text { gardens }\end{array}$ & & & \\
\hline \multirow[t]{2}{*}{ sylvatica } & Greece & & $\begin{array}{l}\mathrm{o} \\
\mathrm{m}\end{array}$ & $\begin{array}{l}5(10) \\
5(10)\end{array}$ & $\begin{array}{l}\text { Mt. Olymp } \\
\text { Pieria } \\
\text { Mountains }\end{array}$ & & & \\
\hline & & & $\mathrm{g}$ & $5(10)$ & $\begin{array}{l}\text { Gardiki, } \\
\text { near Lamia }\end{array}$ & & & \\
\hline $\begin{array}{l}\text { sylvatica } \\
\text { var. } \\
\text { moesiaca }\end{array}$ & Greece & & & 5 & Mt. Olymp & & & \\
\hline
\end{tabular}

For $F$. sylvatica from Greece (o,g,m) 30 samples were examined with chloroplast microsatellites, 15 of these samples were analyzed with AFLPs. F. orientalis from Turkey were sampled from a provenance test at Eutin. 
Table 2. - Frequencies of chloroplast types in $\mathrm{ccmp} 7$ (fragment size in base pairs, bp) and differential amplification of AFLP E37/M68-130 bp.

\begin{tabular}{|c|c|c|c|c|c|c|c|c|c|c|c|c|}
\hline \multirow[t]{4}{*}{ region } & \multirow[t]{4}{*}{ name } & \multirow[t]{4}{*}{ taxon } & \multicolumn{8}{|c|}{ chloroplast type } & \multicolumn{2}{|c|}{ AFLP130 } \\
\hline & & & 1 & 2 & 3 & 4 & 5 & 6 & 7 & 8 & & \\
\hline & & & 145 & 146 & 147 & 148 & 149 & 150 & 151 & 152 & present & absent \\
\hline & & & $\mathrm{bp}$ & $\mathrm{bp}$ & bp & bp & bp & bp & bp & bp & & \\
\hline Düzce & Duezce & orient. & & & & 5 & 2 & & 3 & & 0 & 10 \\
\hline Covakici & Cova & orient. & & & 1 & & 5 & & & & 0 & 10 \\
\hline Karabük & Kara & orient. & 2 & 6 & & & & & & & 2 & 8 \\
\hline Inegöl & Ineg & orient. & & & & 4 & 2 & 4 & & & 0 & 10 \\
\hline Devrek & Devre & orient. & 10 & & & & & & & & 4 & 6 \\
\hline Akkus & Akkus & orient. & & & & 2 & 1 & 4 & & & 0 & 10 \\
\hline Catalca & Catal & orient. & & & & & 3 & 3 & & & 0 & 10 \\
\hline Izmit & Izmit & orient. & & & 2 & 6 & & & & & 0 & 10 \\
\hline $\begin{array}{c}\text { bot. } \\
\text { gardens }\end{array}$ & orient & orient. & 1 & & 1 & & & & & 4 & 1 & 5 \\
\hline Lower & syl & sylv. & 13 & & & & & & & & 11 & 2 \\
\hline Saxony & & & & & & & & & & & & \\
\hline Greece & $\mathrm{o}, \mathrm{m}$, & sylv. & & & & 30 & & & & & 3 & 11 \\
\hline Olymp & moe & $\begin{array}{c}\text { var. } \\
\text { moe- } \\
\text { siaca }\end{array}$ & 5 & & & & & & & & 3 & 2 \\
\hline
\end{tabular}

F. sylvatica populations from Greece is present in $F$. orientalis populations Düzce, Inegöl, Akkus and Izmit (Table 2).

From all populations of northern Turkey only population Devrek is fixed on one chloroplast type (type1, Table 2).

\section{AFLP analysis}

About 300 fragments have been generated using two selective AFLP primer combinations (E38/M64; E37/M68). In a preleminary investigation we screened 8 samples of Fagus sylvatica and 6 samples of $F$. orientalis. We found 39 fragments that were either preferentially amplified in $F$. sylvatica or $F$. orientalis, respectively. The fragments were used in the analysis of all 133 samples. For control, all AFLP reactions were repeated for 14 samples. The UPGMA dendrogram based on the mean number of pairwise character differences revealed three major clusters. Replicated samples always cluster together (Figure 2, samples designated with a and b). Most F. orientalis collected from the forest botanical gardens in Göttingen and Hann. Münden form a separate "upper" group due to many common characters indicating a common origin (see below) The remaining samples from defined origins cluster in two large groups. One group (cluster 1 ) contains $F$. orientalis samples from northern Turkey and two $F$. orientalis from the forest botanical garden in Göttingen (orient 1, orient 5) plus one sample of $F$. sylvatica from Greece (04). The "lower" cluster (cluster 2) comprises $F$. sylvatica from Germany and Greece, but also nine out of ten samples from population Devrek and two samples from the neighbouring population Karabük from northern Turkey originally described as F. orientalis (Table 1, Figure 2). The mean character difference between cluster 1 and cluster 2 is $25.9 \%$ (see Figure 3). In a neighborjoining analysis with 100 bootstrap replicates only the "upper" $F$. orientalis group from the botanical gardens is well supported (Figure 2). Significant bootstrap values are otherwise only observed for replicated samples and two samples from population Catalca (Figure 2).

\section{Comparison of cpDNA and nuclear AFLP}

In cluster 2 chloroplast type 1 and 4 can be observed. Samples from populations Devrek and Karabük from northern Turkey that cluster together with $F$. sylvatica revealed chloroplast type 1 (145 bp at ccmp 7) of F. sylvatica (Figure 2, Table 2). Samples described as $F$. sylvatica var. moesiaca from Mt.

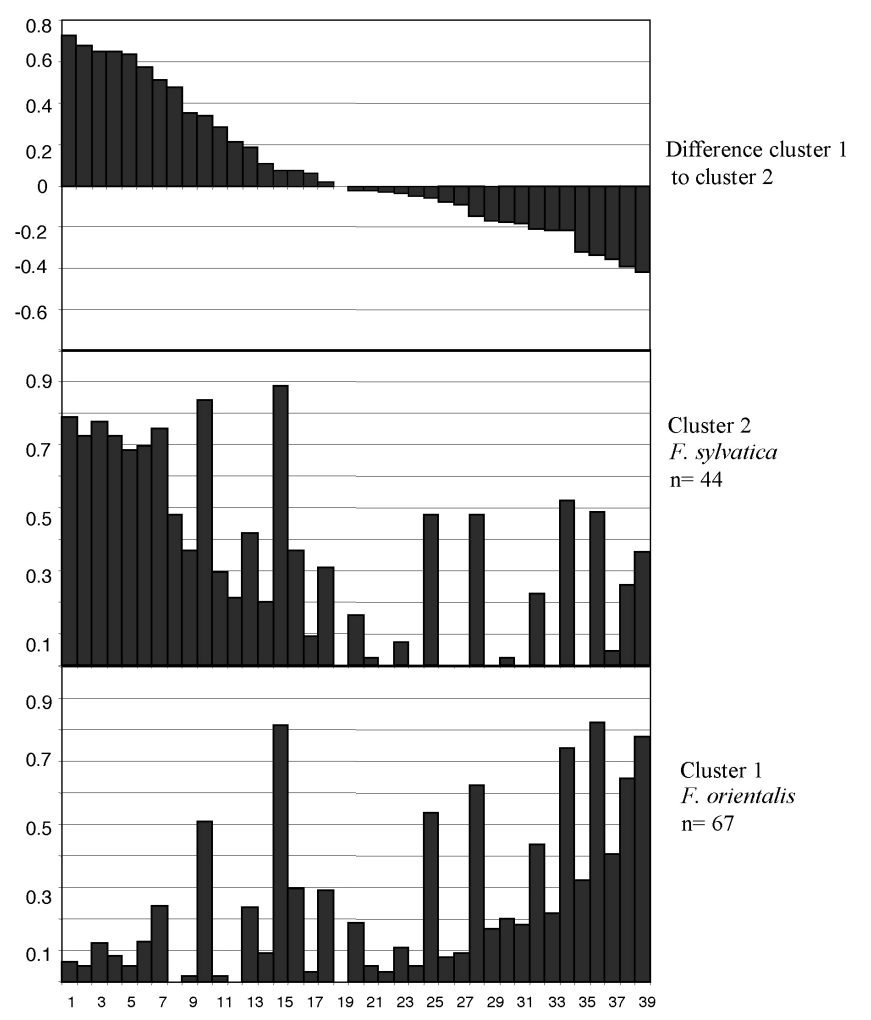

Figure 3. - Differences in the frequencies of AFLP bands in samples of cluster 2 (F. sylvatica cluster) and cluster 1 (F. orientalis cluster) are shown for all 39 AFLP fragments (upper part). The corresponding relative frequencies of AFLP bands in samples of $F$. sylvatica cluster 2 and $F$. orientalis cluster 1 are displayed in the middle and lower part of the Figure.

Olymp (Greece) also have chloroplast type 1 . The remaining $F$. sylvatica samples from Greece show chloroplast type 4 (Figure 2 , dark grey).

In cluster 1 ( $F$. orientalis cluster) ccmp 7 is highly variable with seven alleles (see above, Table 2). Chloroplast type 1 is present in two samples (Devrek50, orient1, shaded in pale grey). These samples also cluster together in the AFLP dendrogram. Chloroplast type 4 is present in 18 samples of the $F$. orientalis cluster (dark grey shades).

The "upper" cluster comprises $F$. orientalis from the forest botanical gardens in Göttingen and Hann. Münden with chloroplast type 8 (152 bp, orient $3,4,7,9)$ and one sample (orient 8 ) with chloroplast type 1 of $F$. sylvatica. Sample orient 8 clusters together with this group based on 15 common AFLP bands (bootstrap value 71, Figure 2) but can be distinguished from all other samples of the "upper" cluster by 8 AFLP bands. Five of these fragments show a significant higher frequency ( $33 \%$ to $73 \%$ higher) in the F. sylvatica cluster than in F. orientalis cluster 1 . The remaining three AFLP bands show no pronounced differences between clusters (less than $10 \%$ ). Orient8 possesses AFLP fragment E37/M68 -130 bp that is otherwise absent in $F$. orientalis cluster 1 and in the "upper" F. orientalis cluster 3.

\section{AFLP bands differing between cluster 1 and 2}

AFLP fragments were sorted according to the degree of differentiation between clusters 1 and 2. Frequencies of amplification products in cluster 1 (F. orientalis from northern Turkey) and cluster $2(F$. sylvatica cluster) are shown for all 39 AFLP fragments in Figure 3 (middle and lower part). The difference in frequencies between cluster 2 and cluster 1 (Figure 3, upper part) is a measure for the utility of the AFLP marker for the 
distinction of these clusters. Amplification products that show the strongest differences in frequencies between clusters (above $60 \%$ ) show high frequencies in the $F$. sylvatica cluster (above $70 \%$ ) and very low frequencies in the $F$. orientalis cluster (Figure 3, upper part). Fragments with high frequencies in the $F$. orientalis cluster can also show relatively high frequencies in the F. sylvatica cluster (Figure 3, right side). None of the bands was diagnostic for the $F$. sylvatica or $F$. orientalis cluster. Thirteen markers show either no amplification product in the $F$. orientalis or in the $F$. sylvatica cluster (Figure 3 ). One of the fragments (E37/M68-130bp) that is absent in the $F$. orientalis cluster and in 11 out of $14 \mathrm{~F}$. sylvatica with chloroplast type 4 from Greece is present in 11 out of 13 F. sylvatica samples from Germany (Table 2). The fragment is also amplified in the two samples from provenance Karabük that cluster with $F$. sylvati$c a$. In population Devrek and in F. sylvatica var. moesiaca presence and absence of the band is evenly distributed (Table 2).

\section{F. orientalis from forest botanical gardens}

Two $F$. orientalis from the forest botanical garden in Göttingen (orient1, orient5) cluster with $F$. orientalis from northern Turkey. One has chloroplast type 1 (orient1), the other has a chloroplast type observed once in population Covakici and twice in population Izmit (147 bp, Table 2). Orient 1 clusters with one sample from population Devrek (Devrek 50), northern Turkey, with the same chloroplast type 1 . The "upper" cluster of $F$. orientalis from forest botanical gardens in Göttingen and Hann. Münden is clearly different from all samples from northern Turkey. These samples are genetically very similar (bootstrap value 96, 35 out of 37 AFLP fragments have an identical amplification pattern) and are clearly separated from all other samples in the AFLP analysis and by a unique chloroplast type (152 bp).

\section{Discussion}

\section{Chloroplast microsatellites}

The occurrence of only one chloroplast type in $F$. sylvatica in Germany is in accordance with earlier studies that showed no variation in chloroplast markers for $F$. sylvatica in central Europe indicating a bottle-neck at the time of postglacial recolonisation. Results obtained from chloroplast markers and allozymes indicate a postglacial recolonization of central Europe from one or few sources (DEMESURE et al., 1996; DounAVI, 2000; GöMÖRY et al., 1999). In the afore mentioned studies no samples from Greece or northern Turkey were included.

The high variation of chloroplast types at ccmp 7 in $F$. orientalis of northern Turkey indicates a glacial refuge in this region. The occurrence of chloroplast type 1 and chloroplast type 4 points to the possibility that one source for postglacial recolonisation of central Europe was located in northern Turkey. Distant populations might have received only a subset of the original diversity of chloroplast types. The observation of only two chloroplast types in Greece - chloroplast type 1 for $F$. sylvatica var. moesiaca from Mt. Olymp, chloroplast type 4 for F. sylvatica populations Mt. Olymp, Piera Mountains and Gardiki - supports this hypothesis.

Because of presumably high mutation rates in chloroplast microsatellites there is certainly a possibility that the same repeat number has evolved independently in different lineages (homoplasy). However, the conformity with other studies based on cpDNA, ITS and allozymes (Demesure et al., 1996; DENK et al., 2002; DounAVI, 2000; GöMÖRY et al., 1999) suggests that chloroplast type 1 of $F$. sylvatica from central Europe has evolved only once and can be traced back to one or a few populations.

\section{AFLP markers}

AFLPs are widely used for genetic mapping, population genetic studies, clone identification and for the determination of intra- and interspecific relationships (COULIBALY et al., 2002; Gailing and Bachmann, 2003; Miyashita et al., 1999; Potokina et al., 2002). Recent studies in different accessions of Arabidopsis thaliana L. and landraces of Vicia sativa L. showed a bimodal distribution of AFLP fragments with a large fraction present in only a few specimen and a second, somewhat smaller, fraction of fragments present in nearly all plants (MIYASHITA et al., 1999; РотокINA et al., 2002). In order to exclude these fragments a priori, only AFLP fragments were selected for further analysis that differentiated between $F$. sylvatica and $F$. orientalis using a limited sample size.

The absence of diagnostic markers for $F$. sylvatica and $F$. orientalis from northern Turkey, respectively, and low structuring in the neighborjoining analysis points to a releatively recent differentiation of Fagus in western Asia and Europe presumably during the cold phases of the Pleistocene (DENK et al., 2002). The UPGMA dendrogram revealed one cluster including all $F$. sylvatica samples and one cluster with exclusively $F$. orientalis from northern Turkey. Samples from Greece (Mt. Olymp, material supplied by V. Meng) that were regarded as intermediate between $F$. orientalis and $F$. sylvatica by morphological criteria (F. sylvatica var. moesiaca) could not be distinguished from $F$. sylvatica by AFLPs or by chloroplast markers (see above). The nine samples from population Devrek and two samples from Karabük in northern Turkey that cluster with $F$. sylvatica could be characterized as $F$. sylvatica by morphological characters. Additional investigations should clarify the possibility of anthropogenic transfer of $F$. sylvatica into this region. In accordance with our results clustering of several morphological characters distinguished two morphotypes in Fagus, one comprised $F$. sylvatica and $F$. sylvatica var. moesiaca, the other F. orientalis from Western Asia (DENK et al., 2002).

Only one sample of F. sylvatica (o4) from Greece (Mt. Olymp) clusters with $F$. orientalis from northern Turkey. Genetic and morphological examinations in this region may reveal a transition zone ("hybrid zone") between $F$. sylvatica and F. orientalis in Greece.

A QTL mapping study of character differences between $F$. orientalis and F. sylvatica (for example, differences in leaf and cupule morphology) could yield information about the mode of character evolution that resulted in different morphotypes in Fagus. Genetic markers that are highly correlated with character differences between $F$. sylvatica and $F$. orientalis might also allow for differentiation between populations of $F$. orientalis and $F$. sylvatica.

It could be promising to map AFLPs that show the strongest frequency differences between $F$. sylvatica and $F$. orientalis cluster from northern Turkey on a genetic linkage map and test for the colocalization with QTLs for morphological differences between taxa. For example, a QTL mapping study performed in an intraspecific cross of Quercus robur L. revealed QTLs for five morphological traits that showed the highest interspecific differences in a mixed stand of $Q$. robur and $Q$. petraea (Matt.) Liebl. and a colocalization of QTLs with interspecific $\mathrm{G}_{\mathrm{st}}$ values (SAINTAGNE et al., 2004).

\section{cpDNA and AFLPs}

In the AFLP dendrogram a $F$. orientalis cluster comprising samples from northern Turkey, a $F$. sylvatica cluster and one "upper" cluster with $F$. orientalis from the forest botanical gardens in Göttingen and Hann. Münden could be distinguished. The $F$. sylvatica cluster contains $F$. sylvatica from Germany and 
F. sylvatica from different locations in Greece but also two samples of population Karabük and nine samples of population Devrek from northern Turkey. At chloroplast microsatellite ccmp 7 these samples show chloroplast type 1 as $F$. sylvatica from Germany. The congruence of AFLP and chloroplast data suggests that genetic variants (morphotypes) similar to $F$. sylvatica are present in the two nearby populations Devrek and Karabük in northern Turkey (see Table 2) and would support the hypothesis that one refuge, from which postglacial recolonisation of central Europe started, was in northern Turkey. Also reinvestigation of morphological characters showed that these samples from northern Turkey are very similar to $F$. sylvatica (unpublished data). However, it can not be excluded that seeds of $F$. sylvatica had been transported by humans to northern Turkey across the Black Sea, although we do not have any evidence for this transfer.

One sample from population Devrek (Devrek 50) with chloroplast type 1 clusters with $F$. orientalis (cluster 1 ) in the AFLP dendrogram pointing to geneflow between nearby populations that are composed of genetic variants similar to $F$. sylvatica or $F$. orientalis, respectively. The observation contradicts the hypothesis that there is only a small contact zone in southeast Europe separating the two allopatric taxa (GöMÖRY et al., 1999). Also clinal variation of morphological characters from Asia minor to Europe (DENK et al., 2002) suggests that there is gene flow between taxa. Additonal studies especially in the predicted contact zones of $F$. orientalis with $F$. sylvatica are necessary in order to determine the extent of gene exchange between these taxa.

\section{Samples from forest botanical gardens}

Two $F$. orientalis samples from the forest botanical garden in Göttingen (orient1, orient 5) group together with $F$. orientalis from northern Turkey pointing to an origin in this region. Orient 1 clusters with Devrek 50 from northern Turkey in the AFLP dendrogram and possesses the same chloroplast type 1 of $F$. sylvatica. These examples illustrate that additional data on $F$. orientalis populations may allow to narrow down the geographical origin of samples from unknown sources (for example, from botanical gardens).

The "upper" group of $F$. orientalis (bootstrap value 96) comprises samples from the forest botanical gardens in Göttingen and Hann. Münden. Since these samples are genetically very similar, it could not be excluded that the seed material originated from a single tree or from closely related trees. Closer investigation revealed that $F$. orientalis from Hann. Münden was grafted onto rootstocks of $F$. sylvatica in the forest botanical garden of Göttingen in 1968 (V. MENG, personal communication). Thus orient 3 , orient 4 from Göttingen and orient 7 , orient 9 from Hann. Münden are most likely one clone. The estimated age of 35 years of orient 3 supports this interpretation. Regarding the conservation of $F$. orientalis in botanical gardens, the applied molecular markers can be used for an inventory of the existing plant material (clone identification) and may help to establish a collection that covers a specific geographic range of $F$. orientalis.

F. orientalis from the botanical garden in Hann. Münden (orient8) clusters with the "upper" F. orientalis in the AFLP analysis, but possesses chloroplast type 1 of $F$. sylvatica from Germany and one AFLP fragment that is not found in F. orientalis clusters (E37/M68-130 bp). Five out of eight AFLP bands that distinguish orient 8 from the other samples in the "upper" cluster show significantly higher frequencies in the $F$. sylvatica cluster than in $F$. orientalis cluster 1 , suggesting that orient 8 might be a hybrid between $F$. orientalis ("upper" cluster) and $F$. sylvatica.

\section{Acknowledgements}

We thank Mrs. O. Dolynska, Mrs. O. Artes and Mr. Th. Seliger for their technical help and Dr. A. C. PAPAgEorgiou, P. SEBEsSE and V. MENG (head of the forest botanical garden in Göttingen) for supplying the material. We are also grateful to the forest service of Turkey to provide the seed samples and to the forest service of Schleswig-Holstein for hosting the beech provenance trial in the forest district of Eutin and to Mrs K. KLEMM and Mr. J. HELLSTRÖM for their help in collecting the material. We are especially grateful to Prof. Dr. FinkeldeY, Prof. Dr. GRUBER and an anonymous reviewer for their helpful comments.

\section{References}

Coulibaly, S., Pasquet, R. S., Papa, R. and Gepts P. (2002): AFLP analysis of the phenetic organization and genetic diversity of Vigna unguiculata L. Walp. reveals extensive gene flow between wild and domesticated types. Theoretical and Applied Genetics 104: 358-366.

Demesure, B., Comps, B. and Petit, R. J. (1996): Chloroplast DNA phylogeography of the common beech (Fagus sylvatica L.) in Europe. Evolution 50: 2515-2520.

Denk, T., Grimm, G., StöGerer, K., Langer, M. and Hemleben, V. (2002): The evolutionary history of Fagus in western Eurasia: evidence from genes, morphology and the fossil record. Plant Systematics and Evolution 232: 213-236.

DounAVI, K. (2002): Familienstrukturen in Buchenbeständen (Fagus sylvatica). Published at http://webdoc.sub.gwdg.de/ diss/2000/dounavi. Dissertation. Göttingen: Institut für Forstgenetik und Forstpflanzenzüchtung, Universität Göttingen.

GAILING, O. and BACHMANN, K. (2003): QTL mapping reveals a two-step model for the evolutionary reduction of inner microsporangia within the asteracean genus Microseris. Theoretical and Applied Genetics 107: 893-901.

Gömöry, D., PAUle, L., Brus, R., Zhelev, P., Tomovic, Z. and GraCAN, J. (1999): Genetic differentiation and phylogeny of beech on the Balkan peninsula. Journal of Evolutionary Biology 12: 746-754.

Huntley, B. and Birks, H. J. B. (1983): An Atlas of Past and Present Pollen Maps for Europe: 0-13 000 Years Ago. Cambridge, London, etc.: Cambridge University Press.

MiYashita, N. T., KaWABE, A. and InNAN, H. (1999): DNA variation in the wild plant Arabidopsis thaliana revealed by amplified fragment length polymorphism analysis. Genetics 152: 1723-1731.

Potokina, E., Blattner, F. R., Alexandrova, T. and Bachmann, K. (2002): AFLP diversity in the common vetch (Vicia sativa L.) on the world scale. Theoretical and Applied Genetics 105: 58-67.

Saintagne, C., Bodenes, C., Barreneche, T., Pot, D., Plomion, C. and KREMER, A. (2004): Distribution of genomic regions differentiating oak species assessed by QTL detection. Heredity 92: 20-30.

SwOFFord, D. L.: PAUP* (1998): Phylogenetic Analysis Using Parsimony (* and other methods). n. Sinauer Assiciates, Sunderland, Massachusetts.

Vos, P., Hogers, R., Bleeker, M., Reijans, M., VAn DE Lee, T., Hornes, M., FriJTERs, A. et al. (1995): AFLP: a new technique for DNA fingerprinting. Nucleic Acids Research 23: 4407-4414.

WeIsInG, K. and Gardner, R. C. (1999): A set of conserved PCR primers for the analysis of simple sequence repeat polymorphisms in chloroplast genomes of dicotyledonous angiosperms. Genome 42: 9-19.

WUEHLISCH, G. V., LiESEBACH, M., MuHs, H.-J. and Stephan, B. R. (1998): A network of international beech provenance trials. In: (Turok. J., Kremer, A., DE VRIES S. G. M., ed^eds). First EUFOGEN Meeting on Social Broadleaves, Bordeaux. IPGRI, Rome. pp. 164-172. 